\title{
High Incidence of Strawberry Polerovirus 1 in the Czech Republic and Its Vectors, Genetic Variability and Recombination
}

\author{
Jana Fránová ${ }^{1, *(\mathbb{D})}$, Ondřej Lenz ${ }^{1}$, Jaroslava Přibylová ${ }^{1}$, Radek Čmejla ${ }^{2}$, Lucie Valentová ${ }^{2}$ and Igor Koloniuk ${ }^{1, *(\mathbb{D})}$ \\ 1 Department of Plant Virology, Institute of Plant Molecular Biology, Biology Centre, Czech Academy of \\ Sciences, 37005 České Budějovice, Czech Republic; lenz@umbr.cas.cz (O.L.); pribyl@umbr.cas.cz (J.P.) \\ 2 Laboratory for Molecular Biology, Research and Breeding Institute of Pomology Holovousy Ltd., \\ Holovousy 129, 50801 Hořice, Czech Republic; radek.cmejla@vsuo.cz (R.Č.); lucie.valentova@vsuo.cz (L.V.) \\ * Correspondence: jana@umbr.cas.cz (J.F.); koloniuk@umbr.cas.cz (I.K.); Tel.: +420-38-777-5535 (J.F.)
}

check for updates

Citation: Fránová, J.; Lenz, O.; Přibylová, J.; Čmejla, R.; Valentová, L.; Koloniuk, I. High Incidence of Strawberry Polerovirus 1 in the Czech Republic and Its Vectors, Genetic Variability and Recombination. Viruses 2021, 13, 2487. https:/ / doi.org/10.3390/v13122487

Academic Editor: Sylvie

German-Retana

Received: 20 November 2021 Accepted: 8 December 2021 Published: 11 December 2021

Publisher's Note: MDPI stays neutral with regard to jurisdictional claims in published maps and institutional affiliations.

Copyright: (c) 2021 by the authors. Licensee MDPI, Basel, Switzerland. This article is an open access article distributed under the terms and conditions of the Creative Commons Attribution (CC BY) license (https:/ / creativecommons.org/licenses/by/ $4.0 /)$.

\begin{abstract}
In total, 332 strawberry plants from 33 different locations in the Czech Republic with or without disease symptoms were screened by RT-PCR for the presence of strawberry polerovirus 1 (SPV1) and five other viruses: strawberry mottle virus, strawberry crinkle virus, strawberry mild yellow edge virus, strawberry vein banding virus, and strawberry virus 1 . SPV1 was detected in 115 tested strawberry plants (35\%), including 89 mixed infections. No correlation between symptoms and the detected viruses was found. To identify potential invertebrate SPV1 vectors, strawberryassociated invertebrate species were screened by RT-PCR, and the virus was found in the aphids Aphis forbesi, A. gossypii, A. ruborum, A. sanquisorbae, Aulacorthum solani, Chaetosiphon fragaefolii, Myzus ascalonicus, and several other non-aphid invertebrate species. SPV1 was also detected in aphid honeydew. Subsequent tests of $C$. fragaefolii and $A$. gossypii virus transmission ability showed that at least $4 \mathrm{~h}$ of acquisition time were needed to acquire the virus. However, 1 day was sufficient for inoculation using $C$. fragaefolii. In conclusion, being aphid-transmitted like other tested viruses SPV1 was nevertheless the most frequently detected agent. Czech SPV1 isolates belonged to at least two phylogenetic clusters. The sequence analysis also indicated that recombination events influence evolution of SPV1 genomes.
\end{abstract}

Keywords: strawberry; mixed virus infection; RT-PCR; virus transmission

\section{Introduction}

More than 30 viral species have been described in strawberries in the past [1], and the number of newly identified viruses is increasing [2-9]. The most economically important and widespread of these viruses are strawberry mottle virus (SMoV), strawberry crinkle virus (SCV), strawberry mild yellow edge virus (SMYEV) and strawberry vein banding virus (SVBV), especially when they occur in mixed infections [1,2,10-12].

In 2015, a novel virus—strawberry polerovirus 1 (SPV1)—was reported in complex viral mixtures in strawberries affected by disease causing acute declines in Canada [4]. Subsequently, cases of SPV1 were reported in the USA [12,13], Argentina [14], and the Czech Republic [7]. SPV1 belongs to the family Solemoviridae, which includes icosahedral plant viruses with small positive-sense RNA genomes approximately $5 \mathrm{~kb}$ in length encoding 4-5 proteins. In addition to vegetative propagation, grafting, and mechanical transmission, some solemoviruses are transmitted by insect vectors [15]. However, the vectors of SPV1 are not yet known.

Therefore, the aim of this study was an epidemiological survey of SPV1 in strawberry plants in the Czech Republic to screen its incidence, to identify its putative vectors (including experimental vector-mediated plant-to-plant transmission), and to assess genetic variability and phylogeny inference of circulating strains. As mixed infections are frequent 
in strawberries, the other most important and widespread strawberry viruses in the region, SMoV (family: Secoviridae, genus: Stramovirus), SCV (family: Rhabdoviridae, genus: Cytorhabdovirus), SMYEV (family: Alphaflexiviridae, genus: Potexvirus), as well as SVBV (family: Caulimoviridae, genus: Caulimovirus), and recently identified strawberry virus 1 (StrV-1, family: Rhabdoviridae, genus: Cytorhabdovirus), were also included in the screening.

\section{Materials and Method}

\subsection{Plant Samples}

During 2016-2021, a total of 332 strawberry plants (296 Fragaria $x$ ananassa Duchesne, 16 F. vesca semperflorens $\mathrm{cv}$. Rujana, 20 woodland $F$. vesca) were sampled from 25 production farms, one nursery plantation, four private gardens and three forests in eight regions in the Czech Republic (Figure S1, Table S1). For high-throughput sequencing (HTS), two symptomatic plants of $F$. ananassa (isolates 34/2016 and 138/2020), and one plant of F. vesca cv. Rujana (isolate 1/2017) showing perspicuous virus-like symptoms [7] were selected. Samples were preferably collected from 2- to 3-year-old strawberry fields.

Leaves of weeds and fruit trees growing near or among the strawberry plants were collected as potential virus reservoirs.

Both $F$. ananassa Duch. cv. Čačanská raná plant and F. vesca 'Alpine' seeds were kindly provided by Mrs. M. Erbenová from the Research and Breeding Institute of Pomology Holovousy in 1993. F. vesca 'Alpine' ('Alpine' below) plants grown from seeds, daughter plants of $F$. ananassa cv. Čačanská raná (ČRM3) grown from runners and $F$. vesca 'Alpine' (No. 814) material graft inoculated from F. ananassa ČRM3 were used to test virus transmission by aphids.

\subsection{Identification of Invertebrates and Honeydew Collection}

Invertebrates were collected from SPV1-positive strawberry plants or trapped in strawberry fields and gardens. Their presumptive identity was determined by the visual examination of morphological characteristics. Total RNA isolated from single aphids or groups (ranging from two to ten individuals) of aphids, ants, enchytraeids and two leafhoppers was forwarded for molecular identification. The primer pair LCO1490/HCO2198 [16] was used to amplify a $658 \mathrm{bp}$ fragment of cytochrome C oxidase subunit 1 (COI) mRNA. The PCR products were either directly subjected to Sanger sequencing or were cloned into the pGEM T-Easy vector (Promega, Road Madison, WI, USA), and plasmid DNAs from selected clones were sequenced using vector-specific primers (Eurofins Genomics, Ebersberg, Germany).

Empty Petri dishes were placed under the leaves of $F$. vesca cv. Rujana (later Rujana; 1/2017) and F. ananassa ČRM3 occupied by Aphis ruborum (A. ruborum) (Börner \& Schilder, 1931) and Chaetosiphon fragaefolii (C. fragaefolii) (Cockerell, 1901). Honeydew was trapped in the dishes overnight, dissolved in RPL extraction buffer $(350 \mu \mathrm{L})$ from a Ribospin Plant purification kit (GeneAll, Seoul, Korea) and used for total RNA extraction, SPV1 amplification and Sanger sequencing.

\subsection{RNA Extraction and cDNA Synthesis, Reverse Transcription Polymerase Chain Reaction (RT-PCR), and Sanger Sequencing}

Total RNA was extracted from $50 \mathrm{mg}$ of the fresh leaf blades of strawberries, weed plants, fruit trees, and from the whole body (aphids and small invertebrates) or head and thorax of insects using either a Gene JET Plant RNA Purification Kit (Thermo Fisher Scientific, Vilnius, Lithuania) or a Ribospin Plant (GeneAll) following the manufacturers' protocols. The quality and quantity of RNA were measured on a Nanodrop 1000 spectrophotometer (Thermo Fisher Scientific). The obtained RNA was reverse-transcribed using the M-MLV Reverse Transcriptase kit (Invitrogen, Carlsbad, CA, USA) according to the manufacturer's recommendation.

The RT-PCR amplification of the mitochondrial NADH dehydrogenase nad5 mRNA using the primers Atropa Nad2.1a/2b was performed as an internal amplification control 
for plant samples and a diet control in invertebrates [17]. Only positive plant samples were subsequently used for virus detection.

For two-step RT-PCR, $1 \mu \mathrm{L}$ of a cDNA preparation was added to a mixture of $10 \mu \mathrm{L}$ of $2 \times$ PPP Master Mix (Top-Bio, Vestec, Czech Republic), $8 \mu \mathrm{L}$ of PCR-grade $\mathrm{H}_{2} \mathrm{O}$, and $0.5 \mu \mathrm{L}$ of each primer $(0.2 \mu \mathrm{M})$. All primers used in the study, their sequences and the corresponding amplification conditions are listed in Table S2. Reaction mixtures devoid of cDNA templates served as no-template controls. Each PCR product $(4 \mu \mathrm{L})$ was analyzed by electrophoresis in a 1\% agarose gel pre-stained with GelRed (Biotium, Hayward, CA, USA). Data on infection counts were analyzed using R software [18] and UpSetR package [19].

The PCR products ( $16 \mu \mathrm{L}$, from plants as well as from invertebrates) were excised from $1.5 \%$ agarose gel and purified using the Expand Combo mini kit (GeneAll). The products were Sanger sequenced from both directions (Eurofins Genomics, Luxembourg).

\subsection{Detection and Quantification of SPV1 in Individual Aphids by RT-qPCR}

Aphis gossypii (A. gossypii) (Glover, 1877), Aphis sanguisorbae (A. sanguisorbae) (Schrank, 1801), and C. fragaefolii adults were collected from native colonies feeding on $F$. ananassa ČRM3 plants that were positive for SPV1, SMoV, SCV, and StrV-1. Total RNA was isolated from individual specimens using TRI reagent (Merck, Kenilworth, NJ, USA). The extracted RNA was quantified using a Nanodrop spectrophotometer and the Qubit HS RNA assay (Thermo Fisher Scientific). cDNA was generated using the Maxima First Strand cDNA Synthesis Kit for RT-qPCR followed by dsDNase treatment (Thermo Fisher Scientific). RT-qPCR was performed with a CFX96 real-time PCR detection system (Bio-Rad, Hercules, CA, USA) and $5 \times$ HOT FIREPol EvaGreen qPCR Mix Plus (Solis BioDyne, Taru, Estonia) reaction mixture. Two endogenous controls, mitochondrial $16 \mathrm{~S}$ ribosomal RNA and succinate dehydrogenase B mRNA, were employed for the normalization of expression levels (Table S2). Each run included positive, negative, no-reverse-transcriptase and no-template controls. All reactions were performed in triplicate using eight biological replicates. The data were analyzed using Bio-Rad CFX Maestro 1.1 (Bio-Rad) and R software [18].

\subsection{Aphid Transmission SPV1 to F. vesca 'Alpine' Plants}

All experiments with aphids were conducted in custom-built mesh cages in an airconditioned greenhouse under a $16 \mathrm{~h}$ light $/ 8 \mathrm{~h}$ dark cycle and temperature at $24{ }^{\circ} \mathrm{C}$.

\subsubsection{Transmission Experiment with Various Acquisition Access and Inoculation} Access Periods

Virus-free colonies of $A$. gossypii and C. fragaefolii were established as individual lines from single newborn 1st-instar aphid and were cultured on seed-grown 'Alpine' plants at $18^{\circ} \mathrm{C}$. Detached leaves from 'Alpine' (No. 814) plant simultaneously infected with SPV1, SMoV and SCV were used as SPV1 source material at the beginning of the study due to the absence of any experimental plants infected with SPV1 alone (Figure S2).

For SPV1 transmission assays, 256 individual A. gossypii wingless adults were divided into 16 groups (each of 16 individuals) with varying acquisition access periods (AAPs) and inoculation access periods (IAPs) of $10 \mathrm{~min}, 4 \mathrm{~h}, 24 \mathrm{~h}$, or $48 \mathrm{~h}$. Following feeding on the leaves of 'Alpine' No. 814 plant, the aphids were transferred to 64 seed-grown 'Alpine' plants (four aphids per plant). Altogether, 16 variants of the transmission trials were conducted, and each experiment was performed in four replicates at $24^{\circ} \mathrm{C}$ (Figure 1).

Each individual group of aphids $(n=64)$ collected from 'Alpine' plants after IAP was tested for the presence of SPV1. After IAP, the 'Alpine' plants $(n=64)$ were sprayed with FAST M (active ingredient: deltamethrin $0.12 \mathrm{~g} / \mathrm{L}$ ) and were examined for the presence of $\mathrm{SPV} 1, \mathrm{SMoV}$, and SCV at 40 days post inoculation (dpi). The plants were monitored for viral disease symptoms daily for 4 months. 
Acquisition access period

SPV1-, SMoV-, SCV-positive Fragaria vesca 'Alpine' (No. 814)

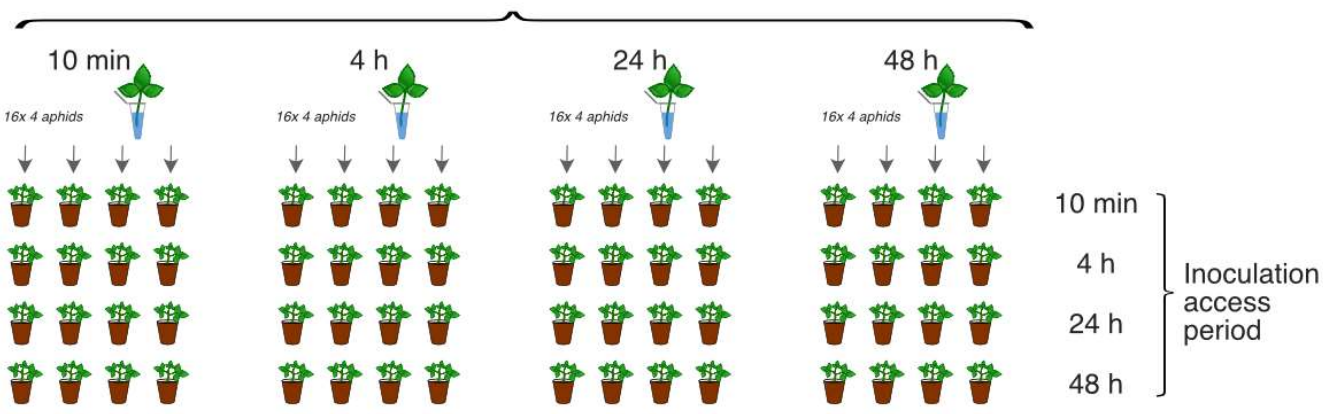

Figure 1. Scheme of the SPV1 transmission experiment using Aphis gossypii. SPV1—strawberry polerovirus $1, \mathrm{SMoV}$ —strawberry mottle virus, SCV—strawberry crinkle virus.

Additionally, C. fragaefolii were transmitted to leaf of the 'Alpine' plant (infected with SPV1 solely; the plant was obtained independently during the study) for AAP of $10 \mathrm{~min}$ and $4 \mathrm{~h}$. After AAP and $1 \mathrm{~h}$ of fasting period, four batches of aphids (each with 4 aphid individuals for each APP) were RT-PCR tested for SPV1 presence.

\subsubsection{Transmission Experiment with Not-Limited AAP and Limited IAP}

Individual adults of $A$. gossypii $(n=40)$ and A. sanguisorbae $(n=20)$ were transferred from native colonies feeding on SPV1-positive F. ananassa ČRM3 plants to 60 plants of F. vesca 'Alpine'. After IAP ( $24 \mathrm{~h}$ for A. gossypii $(n=40)$ and A. sanguisorbae $(n=10)$ and $48 \mathrm{~h}$ for A. sanguisorbae $(n=10))$, each individual aphid was analyzed by RT-qPCR for the presence of SPV1 using the primers SPV-12f/2r (Table S2). The amplification of COI mRNA [16] was performed as an aphid endogenous control. The recipient plants $(n=60)$ were processed similarly at $60 \mathrm{dpi}$.

\subsubsection{Transmission Experiment with Not-Limited AAPs and IAPs}

Eight individuals of $C$. fragaefolii collected from a Rujana 7/2017 plant (positive for SPV1, SMoV, SCV, SMYEV, and StrV-1) were transferred to 'Alpine' plant. After one month of cultivation at $24{ }^{\circ} \mathrm{C}, 10$ aphids were tested for the presence of SPV1 and other viruses. Plant was sprayed with FAST M and, after 10 days, was examined by RT-PCR for the presence of the viruses.

Similarly, batches of C. fragaefolii aphids were transmitted from F. vesca 'Alpine' (infected with SPV1 solely) to F. vesca 'Alpine' plants for IAPs of $10 \mathrm{~min}, 4 \mathrm{~h}, 8 \mathrm{~h}, 1$, 2, 3, 5, 7, 11,14 , and 17 days. Following the IAP, plants were sprayed with FAST M. After one month, the plants were examined by RT-PCR for the presence of viruses and were continuously observed for disease symptoms.

\subsection{HTS and Sequence Analyses}

Sequencing libraries were prepared using the Collibri Stranded RNA Library Prep Kit for Illumina (Thermo Scientific) from total RNA previously depleted of ribosomal RNA with a RiboMinus kit (Thermo Scientific) following the manufacturer's recommendations. After quantification and quality control, the libraries were processed using NovaSeq6000. The obtained $150 \mathrm{bp}$ paired-end reads were quality and adapter trimmed and analyzed with CLC Genomics Workbench 9.5.1 (Qiagen, Hilden, Germany). Briefly, the trimmed reads were de novo assembled with minimum contig size of $450 \mathrm{bp}$. The resulting sequences were compared against local database of custom viral proteins using BLASTx (E-value cutoff 1e-5) in Geneious Prime 2021.1.1 (Biomatters Ltd., Auckland, New Zealand). The potential viral hits were then compared against GenBank nr database (20 October 2021; e-value cutoff 1e-3). Sequence alignments and phylogenetic trees were produced using Geneious 9.1.8 (Biomatters Ltd., Auckland, New Zealand) and Geneious-integrated tools (ClustalW, MAFFT, GeneiousTree builder (Jukes-Cantor distance model, Neigbour-joining method, 
bootstrap with 1000 replicates)). Recombination analyses of the obtained alignments were performed with RDP5 software (RDP, v. 5.05 Beta) with default settings and window size $=50$ [20]. Synonymous and nonsynonymous mutations were manually counted from the aligned nucleotide sequences, with translations displayed in the Geneious software.

\section{Results}

\subsection{Symptoms and Virus(es) Presence}

The visual inspection of strawberry farms, nurseries, private gardens, and woodland strawberries mostly revealed a low incidence of symptomatic plants. Therefore, plants with virus-like symptoms ( $251 \mathrm{~F}$. ananassa, $12 \mathrm{~F}$. vesca semperflorens, and 6 forest $F$. vesca plants) were preferentially sampled over asymptomatic strawberries (45 F. ananassa, $4 \mathrm{~F}$. vesca semperflorens, and 14 forest $F$. vesca plants). Symptoms observed on the strawberry plants ranged from chlorosis, mosaic, irregular vein clearing and necrosis, and the reddening and deformation of leaves to stunting and whole-plant decline (Figures 2 and 3). The most common symptoms were dwarfism and chlorosis. An overview of the strawberry plants, their symptoms, and the detection of SPV1, SMoV, SCV, SMYEV, SVBV, and StrV-1 is shown in Table S1.

Up to $80 \%$ of plants were observed to be symptomatic among older plantings of $F$. ananassa cv. Elkat on two strawberry farms in the Moravian-Silesian Region (locality MS-1F, MS-2-F). The infected plants often showed irregular vein clearing and necrosis and/or mosaic (Figure 2). Viruses were detected in both symptomatic and symptomless plants.

Prominent leaf reddening and general weakening of plant growth were observed among F. ananassa plants at a farm in the Pilsen Region in 2020 (locality P-1-F, Figure 3A). SPV1, SMoV, and SCV were previously detected on this farm in 2017. In 2020, all 31 examined plants were infected with different combinations of SMoV, SCV, SMYEV, and SPV1. Neither SVBV nor the recently described cytorhabdovirus StrV-1 were found at that location.

At the Z-1-F locality in the Zlín Region (Figure 3B), severe preliminary leaf reddening, irregular shapes, chlorosis of young leaves, and declines of plants were observed; $\mathrm{SMoV}$ $(n=2)$, SCV $(n=1)$, and SMYEV $(n=1)$ were found at this site sporadically among 22 examined plants. Twelve plants showing decline and dieback symptoms were RT-PCR negative for the tested viruses. We also detected the presence of the fungal agents Alternaria sp., Coniella fragariae, Fusarium sp., Pythium sylvaticum, Rhizoctonia sp., and Verticilium sp. (data not shown). Similar symptoms of leaf reddening and death of plants were found on another farm (South Moravian Region, locality SM-5-F) and in the Olomouc Region (locality O-1-F) (Table S1).

There were plants lacking any symptoms of viral disease at some sites. At one location (Zlín Region, locality Z-2-F), only a slight stunting of plants was observed, and the viruses were not detected at that site.

Among 45 examined symptomless $F$. ananassa plants, 29 plants (64\%) were tested negative for virus presence. However, the remaining plants were virus-positive, with either single (SPV1, SCV, or SMoV) or mixed infections (different combinations of SPV1, SMoV, SCV, SMYEV, and StrV-1; Table S1).

For $F$. ananassa samples, a chi-square test of independence showed that there was no significant association between one of the tested viruses and symptomatic phenotype $(\mathrm{X} 2(5, n=1775)=0.0005, p=0.99)$, thus excluding association of any particular virus and observed symptoms. Then, comparison of symptomatic samples showed strong association with virus presence $\left(\mathrm{X} 2(1, n=1775)=87.63, p=7.9 \times 10^{-21}\right)$ regardless of its nature (either viral species or single/mixed infection), meaning there was a significant relationship between virus infection and observed symptoms. 


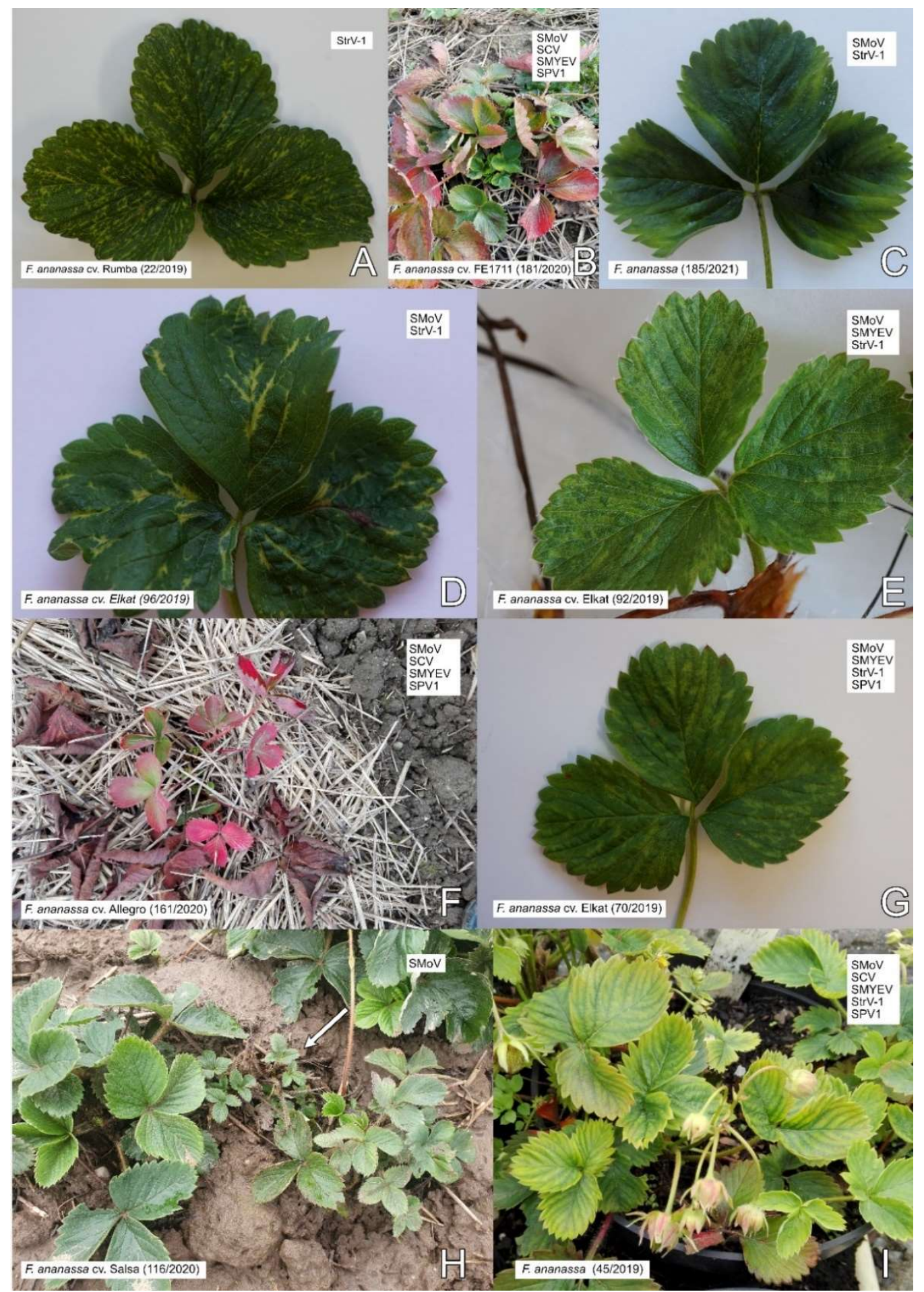

Figure 2. Virus-like disease symptoms on strawberries: (A,D) irregular vein clearing; (B) premature reddening of older leaves and chlorosis of young leaves; $(\mathbf{C})$ chlorosis of veins at the leaf margin; $(\mathrm{E}, \mathrm{G})$ mosaic; $(\mathrm{F})$ premature dieback and reddening of older leaves together with weakening of the plant; (H) stunting (arrow); (I) chlorosis of the whole plant. The identification of plants, cultivars, and viruses detected by RT-PCR is indicated in the figure. SMYEV—strawberry mild yellow edge, StrV1—strawberry virus 1. 


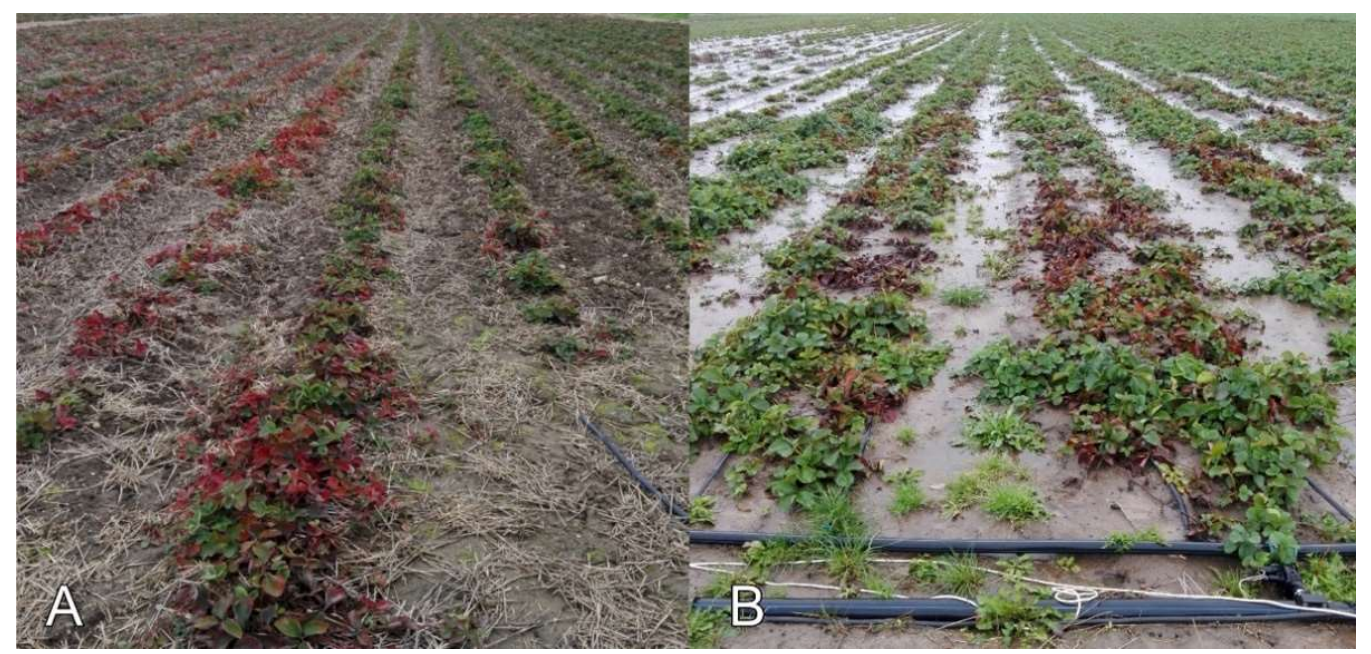

Figure 3. Fields with strawberry plants affected by decline syndrome at P-1-F and Z-1-F sites in Pilsen (A) and the Zlín (B) regions.

Sixty plants of $F$. vesca cv. Rujana were grown from seeds purchased in a shop and had been cultivated in a private garden in Třísov, South Bohemia, (locality SB-10-G) since spring 2016. During 2016, increasingly severe virus-like symptoms were observed in a growing number of plants. By April 2017, all plants already had symptoms of mosaic, leaf and flower malformation, and dwarfing, and some plants were declining. All randomly selected plants $(n=11)$ were positive for SPV1 in combination with SMoV, SCV, StrV-1, and SMYEV. At the end of 2017, all plants were removed from the garden. In 2018, 30 seed-grown strawberries were planted approximately $50 \mathrm{~m}$ from the original garden. Following disease symptom appearance, five plants were tested in September 2019. RT-PCR showed the presence of StrV-1 in a plant with dwarfism and mosaic symptoms and SPV1 in combination with SCV and StrV-1 in one symptomless plant. Colonies of C. fragaefolii, A. ruborum, A. sanguisorbae, and Aulacorthum solani (A. solani) (Kaltenbach, 1843) aphids were notably found on the plants in both 2017 and 2019.

\subsection{Incidence of SPV1, Frequency of Mixed Infections}

Among the tested viruses, SPV1 was the most frequently found $(n=115 ; 35 \%)$, followed by SMoV $(n=100 ; 30 \%)$, SMYEV $(n=96 ; 29 \%)$, SCV $(n=88 ; 27 \%)$, and StrV$1(n=70 ; 21 \%)$ (Figure 4). In F. ananassa plants, RT-PCR revealed SPV1 either alone $(n=26)$ or in coinfections with other tested viruses $(n=77)$. All 12 SPV1-positive $F$. vesca cv. Rujana garden plants were coinfected with either two or three other viruses $(\mathrm{SMoV}, \mathrm{SCV}$, and StrV-1). An isolate of SVBV (67/2019) was identified in only one plant of F. ananassa cv. Faith (locality MS-2-F), and its complete sequence was deposited in GenBank under Acc. No. MW387997. The only viruses found to infect $F$. vesca in the forest were $\mathrm{SMoV}$ and StrV-1 (locality SB-8-W and SB-12-W), while SMoV, SCV, and StrV-1 were detected in wild-grown F. vesca as well as cultivated F. ananassa in a garden (locality SB-9-G, Table S1). 


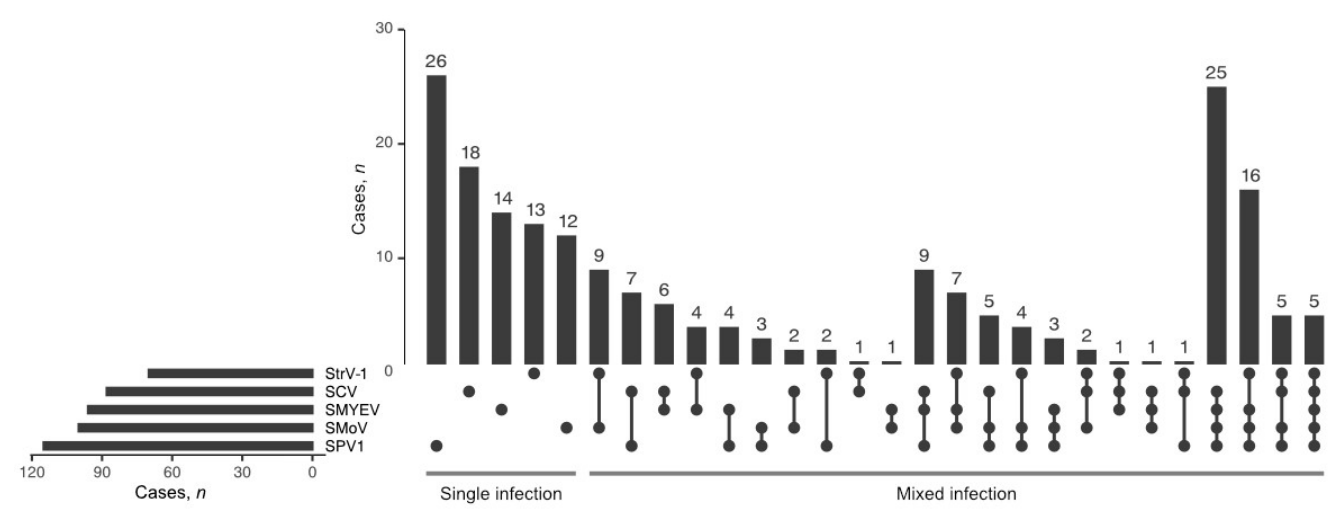

Figure 4. An Upset plot of the coinfection of 332 plant samples by SMoV, SCV, SMYEV, StrV-1, and SPV1.

The production fields with the highest virus incidences were located in two strawberry farms (localities P-1-F and MS-2-F) in the Pilsen and Moravian-Silesian regions (distance, approximately $450 \mathrm{~km}$; only farms where more than five plants were examined were included in the analysis). SPV1 was repeatedly identified in samples collected at these sites during 2017-2020. The tested viruses were also detected in nine newly planted symptomless seedlings from the MS-2-F locality. The growers at the examined sites use their own plant propagation material to some extent; strawberry plants are grown in the same plot (or in the close vicinity of older plantings), and C. fragaefolii occurrence was recorded at the Moravian-Silesian site. In contrast, at one farm in the Zlín Region (locality Z-2-F) where self-propagated material was also used, neither symptoms (except for mild dwarfism probably caused by the cyclamen mite, Phytonemus pallidus (Banks, 1901)) nor any of the tested viruses were recorded (Table S1). At another site in the Zlín Region (locality Z-1-F) where C. fragaefolii aphids were frequently found and the seedlings originated from the Netherlands, no SPV1 occurrence was recorded among 29 examined plants, and only a few plants were SMoV, SCV, or SMYEV positive. An increase in SPV1 positivity was recorded in production fields in South Bohemian Region (locality SB-2-F, Table S1). There was only one SPV1-positive plant of F. ananassa cv. Darselect among 8 plants screened there in 2019, but there were already 9 positive plants among 17 tested in 2020.

Altogether, SPV1 was detected in a breeding nursery (Liberec Region) and in 16 out of 25 production strawberry farms. The only regions where SPV1 was not detected were Olomouc and Zlín (Figure 5).

\subsection{Putative Vectors and Non-Strawberry Hosts of SPV1}

None of the 19 non-strawberry plant species growing in close vicinity to the sampling sites were identified as a natural SPV1 host (Appendix A). On the contrary, SPV1 was detected in several strawberry-associated aphid species (e.g., Aphis forbesi (A. forbesi) (Weed 1889), A. gossypii, A. ruborum, A. sanguisorbae, A. solani, Myzus ascalonicus (M. ascalonicus) (Doncaster 1946) and C. fragaefolii (Appendices B and C). Following the SPV1 detection we estimated viral titers in individual aphids of $A$. sanguisorbae, A. gossypii and $C$. fragaefolii. Based on the results (Appendix D), melon aphid, A. gossypii, was selected as an optimal vector for further transmission experiments. 


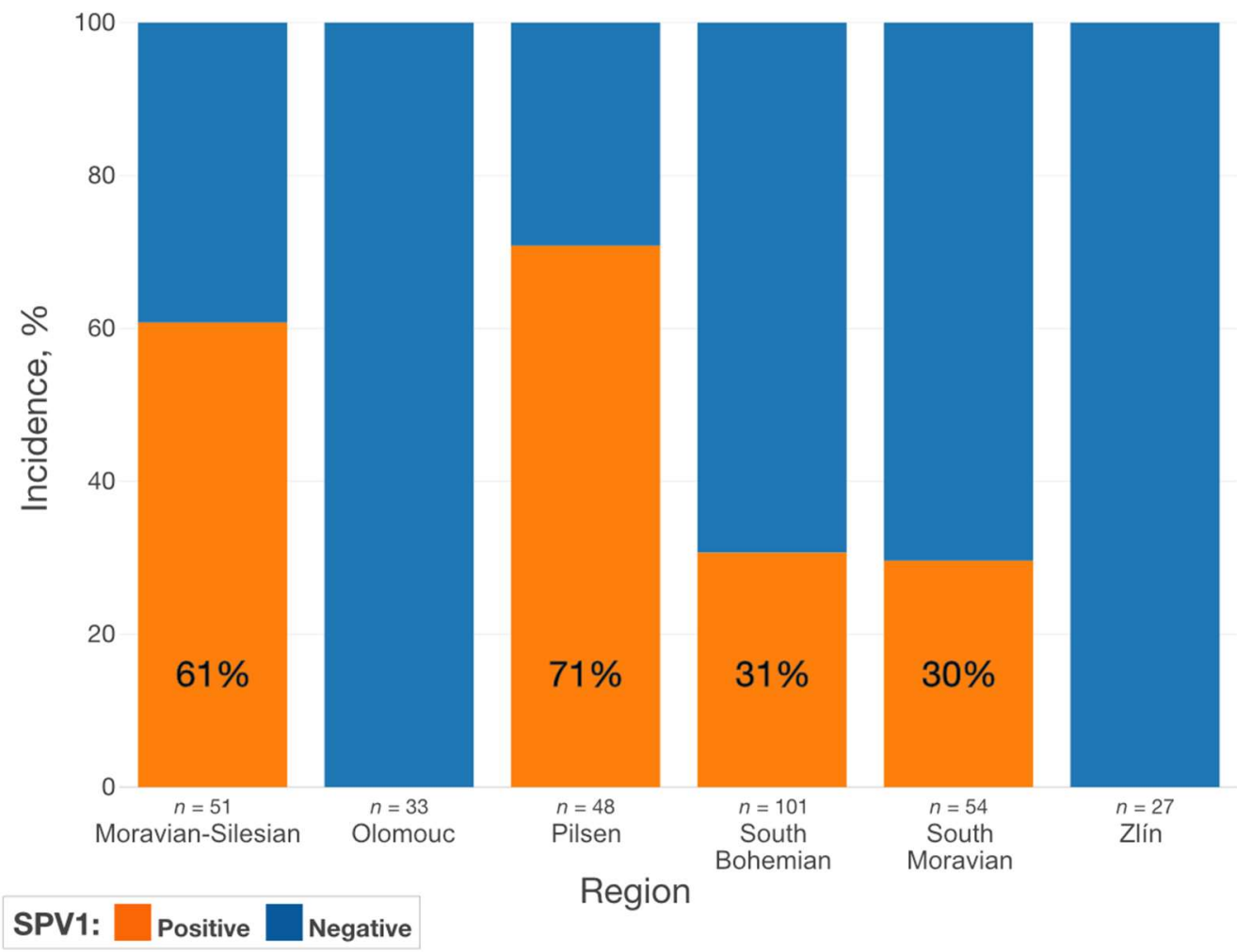

Figure 5. Prevalence of SPV1 infection by a region.

\subsection{Aphid-Mediated Transmission}

To support the findings of putative aphid vectors we tested aphids' ability to transmit SPV1. Transmission trials performed using 16 combinations of different AAPs and IAPs with A. gossypii and F. vesca 'Alpine' No. 814 did not result in SPV1 transmission to 'Alpine' seedlings under the experimental conditions. All 64 recipient plants were negative for SPV1 by RT-PCR, while 19 of the 64 aphid batches used for inoculation were SPV1 positive. The highest ratio of positive aphids was obtained from the $48 \mathrm{~h}$ AAP (13 positive batches out of 16 tested). A period of at least four hours was needed for A. gossypii to acquire SPV1 (2 positive batches out of 16 tested, Table S3). No aphids were SPV1-positive by RT-PCR after a 10 min AAP. On one recipient plant, pronounced mosaic symptoms appeared on newly emerging leaves from $5 \mathrm{dpi}$ onwards. The plant was later shown to be $\mathrm{SMoV}$ positive (48 h AAP, $4 \mathrm{~h}$ IAP; Figure S3). The other 'Alpine' plants remained asymptomatic. Similarly, four hours were needed for $C$. fragaefolii to acquire SPV1 (all four examined aphids' batches were RT-PCR positive).

Using eight individuals of $C$. fragaefolii feeding on $F$. vesca cv. Rujana 7/2017 subjected to an IAP of 1 month, SPV1 and SCV were identified by RT-PCR and Sanger sequencing in the F. vesca 'Alpine' recipient plant (SPV1: 1679 nt; Acc. No MW387977) as well as in aphid offspring. The 'Alpine' plant showed symptoms of epinasty, irregular vein clearing, leaf malformation, and light chlorotic spots on newly growing leaves (Figure S4). RT-PCR testing for other viruses (SMoV, StrV-1, and SMYEV) returned negative results.

Moreover, 'Alpine' plants subjected to IAPs of 1, 2, 3, 5, 7, 11, 14 and 17 days with C. fragaefolii were found to be positive for SPV1 by RT-PCR. No disease symptoms were observed on eight SPV1-positive 'Alpine' plants.

When individual A. gossypii and A. sanguisorbae aphids were used to transfer SPV1 from F. ananassa ČRM3 (IAP 24 and 48 h), none of the 60 'Alpine' recipient plants were found to be positive for SPV1 by RT-qPCR at $60 \mathrm{dpi}$. However, all 60 aphids tested positive for SPV1. The $\mathrm{Ct}$ values varied from 18 to 31 (median $\mathrm{Ct} 27$ ). The internal control (amplification of the COI gene sequence) revealed Ct values of 21 to 27 (median $\mathrm{Ct} 23$ ), 
while no amplification of the internal control specific for plant genetic material (ndhB mRNA) was observed.

\subsection{HTS Sequencing and Variability of SPV1 Isolates}

In total, SPV1 isolates from twenty-two strawberry plants, six arthropods, two indicator 'Alpine' plants and one honeydew sample were subjected to Sanger sequencing and deposited in GenBank. Furthermore, the nearly complete genomes (complete all CDSs) of three isolates were obtained by de novo assembly of HTS reads (Table 1). The nt and aa sequences of $F$. ananassa SPV1 isolates from different locations were nearly identical (19 isolates shared 99 to $100 \%$ identity of the nt sequences of a $1600 \mathrm{nt}$-long fragment of P1-P2; two whole-genome sequences were 99.5\% identical) and differed from those of the isolates of Rujana (the maximal identities of $F$. ananassa isolates to the Rujana sequences were $97 \%$ for the 1600 nt-long fragment of the P1-P2 genes and 95\% for whole-genome sequences).

Table 1. Comparison of SPV1 sequenced with GenBank isolates (nucleotide BLAST).

\begin{tabular}{|c|c|c|c|c|c|c|}
\hline \multicolumn{4}{|l|}{ Sample } & \multicolumn{3}{|c|}{ Related SPV1 Sequence } \\
\hline \multirow[t]{2}{*}{ Isolate } & $\begin{array}{l}\text { Plant/Arthropod } \\
\text { Tested }\end{array}$ & Part of Genome & GenBank & $\%$ Identity & & \\
\hline & & & Acc. No. & (Length) & Acc. No. & Origin \\
\hline \multicolumn{7}{|c|}{ Prague Region } \\
\hline CB315 & $\begin{array}{l}\text { F. ananassa cv } \\
\text { Darselect }\end{array}$ & P1-P2 gene & MW387989 & $99.4(1696)$ & KM233706 & Canada \\
\hline \multicolumn{7}{|c|}{ Central Bohemian Region } \\
\hline CB191 & $\begin{array}{l}\text { F. ananassa cv } \\
\text { Darselect }\end{array}$ & P1-P2 gene & MW387986 & $99.4(1691)$ & KM233706 & Canada \\
\hline \multicolumn{7}{|c|}{ South Bohemian Region } \\
\hline $35 / 2017$ & $\begin{array}{l}\text { F. ananassa cv } \\
\text { Darselect }\end{array}$ & P1-P2 gene & MW387980 & $99.5(1674)$ & KM233706 & Canada \\
\hline $23 / 2020$ & $\begin{array}{l}\text { F. ananassa cv } \\
\text { Darselect }\end{array}$ & P1-P2 gene & MW387994 & $99.5(1696)$ & KM233706 & Canada \\
\hline $34 / 2016$ & F. ananassa & complete CDSs & MW387996 & $99.1(5947)$ & MZ328110 & Canada \\
\hline $1 / 2017$ & $\begin{array}{l}\text { F. vesca semperflorens } \mathrm{cv} \\
\text { Rujana }\end{array}$ & complete CDSs & MW387995 & $96.0(5948)$ & MK142237 & Argentina \\
\hline 1/2017-Нo & $\begin{array}{l}\text { Aphis ruborum's } \\
\text { honeydew }\end{array}$ & P1-P2 gene & MW387973 & $97.3(1691)$ & MZ351170 & USA \\
\hline 1/2017-Ar & Aphis ruborum & P1-P2 gene & MW387976 & $97.3(1693)$ & MZ351170 & USA \\
\hline 1/2017-Ma & Myzus ascalonicus & P1-P2 gene & MW387974 & $96.9(2416)$ & MZ351170 & USA \\
\hline 1/2017-Rh & Rhyparochromidae sp. & P1-P2 gene & MW387975 & $97.4(1211)$ & MZ351170 & USA \\
\hline $7 / 2017$ & $\begin{array}{l}\text { F. vesca semperflorens } \mathrm{cv} \\
\text { Rujana }\end{array}$ & P5-gene & OL421566 & $96.5(1439)$ & MK142237 & Argentina \\
\hline 7/2017-FvA2 & F. vesca cv Alpine & P1-P2 gene & MW387977 & $97.3(1679)$ & MZ351170 & USA \\
\hline 7/2017-FvA2 & F. vesca cv Alpine & P5-gene & OL421567 & 96.5 (1439) & MK142237 & Argentina \\
\hline 814-Ag_444 & Aphis gossypii & P5-gene & OL421569 & $99.2(1424)$ & KM233705 & Canada \\
\hline 814-Ag_505 & Aphis gossypii & P5-gene & OL421570 & $99.2(1439)$ & KM233705 & Canada \\
\hline $814-F v A$ & F. vesca cv Alpine & P5-gene & OL421568 & $99.2(1439)$ & KM233705 & Canada \\
\hline
\end{tabular}


Table 1. Cont.

\begin{tabular}{|c|c|c|c|c|c|c|}
\hline \multicolumn{4}{|l|}{ Sample } & \multicolumn{3}{|c|}{ Related SPV1 Sequence } \\
\hline \multirow[t]{2}{*}{ Isolate } & $\begin{array}{l}\text { Plant/Arthropod } \\
\text { Tested }\end{array}$ & Part of Genome & & $\%$ Identity & & \\
\hline & & & Acc. No. & (Length) & Acc. No. & Origin \\
\hline \multicolumn{7}{|c|}{ Pilsen Region } \\
\hline $116 / 2017$ & $\begin{array}{l}\text { F. ananassa cv } \\
\text { Christine }\end{array}$ & P1-P2 gene & MW387981 & $99.4(1666)$ & KM233706 & Canada \\
\hline $160 / 2020$ & F. ananassa cv Allegro & P1-P2 gene & OL421564 & $99.3(1696)$ & KM233706 & Canada \\
\hline $169 / 2020$ & F. ananassa cv Laetitia & P1-P2 gene & OL421565 & $99.2(1696)$ & KM233706 & Canada \\
\hline $132 / 2017$ & $\begin{array}{l}\text { F. ananassa cv } \\
\text { Darselect }\end{array}$ & P1-P2 gene & MW387982 & $99.1(1627)$ & KM233706 & Canada \\
\hline $136 / 2017$ & $\begin{array}{l}\text { F. ananassa cv } \\
\text { Darselect }\end{array}$ & P1-P2 gene & MW387983 & $99.4(1669)$ & KM233706 & Canada \\
\hline \multicolumn{7}{|c|}{ Ústí nad Labem Region } \\
\hline CB129 & F. ananassa cv Sonata & P1-P2 gene & MW387985 & $99.4(1689)$ & KM233706 & Canada \\
\hline \multicolumn{7}{|c|}{ Liberec Region } \\
\hline $\mathrm{T} 22 / 2016$ & F. ananassa & P1-P2 gene & MW387978 & $99.2(1693)$ & KM233706 & Canada \\
\hline T22/2016-Af & Aphis forbesi & P1-P2 gene & MW387979 & $99.1(1686)$ & KM233706 & Canada \\
\hline \multicolumn{7}{|c|}{ Hradec Králové Region } \\
\hline CB256 & $\begin{array}{l}\text { F. ananassa cv } \\
\text { Darselect }\end{array}$ & P1-P2 gene & MW387988 & $99.4(1694)$ & KM233706 & Canada \\
\hline \multicolumn{7}{|c|}{ Vysočina Region } \\
\hline CB231 & $\begin{array}{l}\text { F. ananassa cv } \\
\text { Darselect }\end{array}$ & P1-P2 gene & MW387987 & $99.5(2370)$ & KM233706 & Canada \\
\hline \multicolumn{7}{|c|}{ South Moravian Region } \\
\hline $185 / 2017$ & $\begin{array}{l}\text { F. ananassa cv } \\
\text { Darselect }\end{array}$ & P1-P2 gene & MW387984 & $99.4(1601)$ & KM233706 & Canada \\
\hline $9 / 2019$ & $\begin{array}{l}\text { F. ananassa cv } \\
\text { Symphony }\end{array}$ & P1-P2 gene & MW387990 & $99.1(1696)$ & KM233706 & Canada \\
\hline $100 / 2019$ & $\begin{array}{l}\text { F. ananassa cv } \\
\text { Symphony }\end{array}$ & P1-P2 gene & MW387993 & $99.1(1696)$ & KM233706 & Canada \\
\hline \multicolumn{7}{|c|}{ Moravian-Silesian Region } \\
\hline $85 / 2019$ & F. ananassa cv Elkat & P1-P2 gene & MW387992 & $99.3(1692)$ & KM233706 & Canada \\
\hline $66 / 2019$ & F. ananassa cv Faith & P1-P2 gene & MW387991 & $99.3(1644)$ & KM233706 & Canada \\
\hline $138 / 2020$ & F. ananassa cv Elkat & complete CDSs & OL421571 & $99.1(5985)$ & MZ328110 & Canada \\
\hline
\end{tabular}

The comparison of the aa sequences of individual genes of 3 Czech and 10 isolates with full-genome sequences in GenBank revealed at least two different phylogenetic clusters, while the Rujana isolates of SPV1 showed the greatest distance from all others (Figure S5). This clustering was supported by the nt and aa sequences of a $1600 \mathrm{nt}$ fragment obtained by the Sanger sequencing of RT-PCR products (Figure S6).

Differences were found between the Rujana isolate and other SPV1 isolates, especially in the P1 and P5 genes. In the P1 gene, the Rujana isolate differed in 99 nts from the reference sequence of SPV1 (NC_025435); in the P5 gene, $90 \mathrm{nts}$ were different. Nevertheless, most of these mutations were synonymous (67 in the P1 gene and 71 in the P5 gene) and did not change the encoded aa residues (Table S4). 


\subsection{Recombination between SPV1 Genomes}

The analysis of nearly full-genome sequences revealed that some parts of four American SPV1 isolates (MZ351169, MZ351170, MZ351171, and MK142237) were highly similar to that of the Rujana isolate (MW387995), while the remainder of their genomes differed substantially. In particular, the MZ351169 (USA) and MZ351171 (USA) sequences shared high similarity to the 5'-end of the P1-P2 gene of the Rujana isolate, and the MK142237 (Argentina) and MZ351170 (USA) sequences showed similarity to the $3^{\prime}$-end of the P5 gene of the Rujana isolate. Detailed analysis with RDP5 software revealed potential recombination points (Table 2) notably in the P1 and P5 genes (Figure 6 and Figure S7). These were further supported by phylogenetic trees of recombined and non-recombined parts of P1 and P5 genes, respectively (Figure 6 and Figure S7).

Table 2. Recombination events detected by RDR5 program between SPV1 isolates. Only recombination events supported by five or more methods were considered; sequences analyzed in detail are in bold. Methods: $R=R D P 5, G=G e n e C o n v, B=$ Bootscan, $\mathrm{M}=$ MaxChi, $\mathrm{C}=$ Chimaera, $\mathrm{S}=$ SiScan, $\mathrm{T}=$ Topal.

\begin{tabular}{|c|c|c|c|c|c|c|c|c|c|c|c|c|}
\hline \multirow{3}{*}{$\begin{array}{l}\text { Sequence } \\
\text { (acc. num.) }\end{array}$} & \multicolumn{4}{|c|}{ Recombination Event Detected } & \multirow{3}{*}{$\begin{array}{c}\begin{array}{c}\text { Average } \\
p \text {-Value }\end{array} \\
\text { (RDP) }\end{array}$} & \multicolumn{7}{|c|}{ Detection Results } \\
\hline & \multicolumn{2}{|c|}{ Region 1} & \multicolumn{2}{|c|}{ Region 2} & & \multirow{2}{*}{$\mathbf{R}$} & \multirow{2}{*}{ G } & \multirow{2}{*}{ B } & \multirow{2}{*}{$\mathbf{M}$} & \multirow{2}{*}{$\mathrm{C}$} & \multirow{2}{*}{$\mathbf{S}$} & \multirow{2}{*}{$\mathrm{T}$} \\
\hline & nt & Gene(s) & nt & Gene & & & & & & & & \\
\hline MK142237 & $1-658$ & P0, P1 & $5276-5990$ & P5 & $1.24 \times 10^{-14}$ & + & + & + & + & + & + & + \\
\hline MZ351170 & $1-1129$ & P0, P1 & $5579-5990$ & P5 & $2.46 \times 10^{-2}$ & + & - & + & + & + & + & + \\
\hline MZ351171 & 889-1660 & P1 & - & - & $1.15 \times 10^{-2}$ & + & + & + & + & + & + & + \\
\hline MZ351169 & 1298-1660 & P1 & - & - & $5.14 \times 10^{-3}$ & + & + & + & + & + & + & + \\
\hline MZ351173 & $1-1624$ & P0, P1 & $5286-5990$ & P5 & $1.64 \times 10^{-4}$ & + & + & + & + & + & + & + \\
\hline MZ328111 & $1-888$ & P0, P1 & $5949-5990$ & - & $1.66 \times 10^{-3}$ & + & + & + & + & + & + & + \\
\hline MZ328111 & $3146-3848$ & P1-2 & - & - & $3.22 \times 10^{-9}$ & + & + & + & + & + & + & + \\
\hline MZ351169 & 1661-2451 & P1-2 & - & - & $1.74 \times 10^{-5}$ & + & + & + & + & + & + & + \\
\hline MZ351171 & $1661-2656$ & P1-2 & - & - & $3.41 \times 10^{-6}$ & + & + & + & + & + & + & + \\
\hline
\end{tabular}

A) $\begin{gathered}\text { non-recombined left part of P5 gene } \\ (4494-5271 \text { nt on NC_25435) }\end{gathered}$

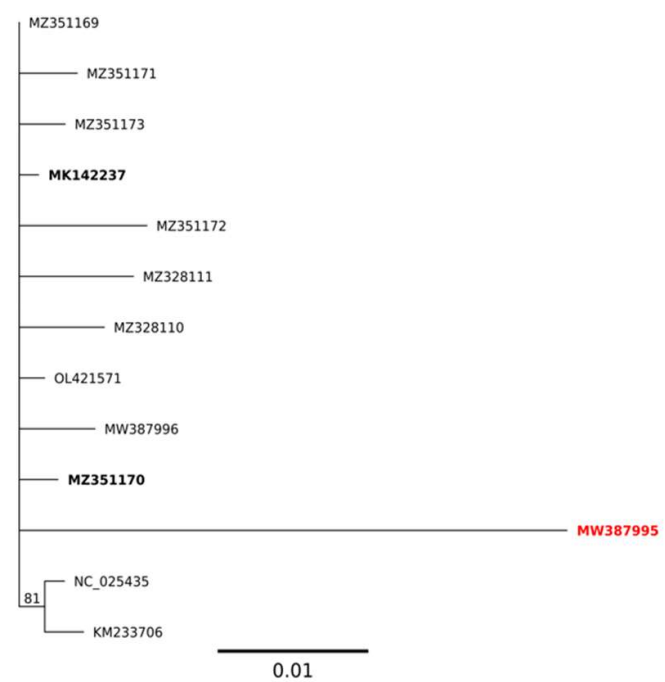

B) $\begin{aligned} & \text { recombined right part of P5 gene } \\ & \text { (5272-5874 nt on NC_ } 025435)\end{aligned}$

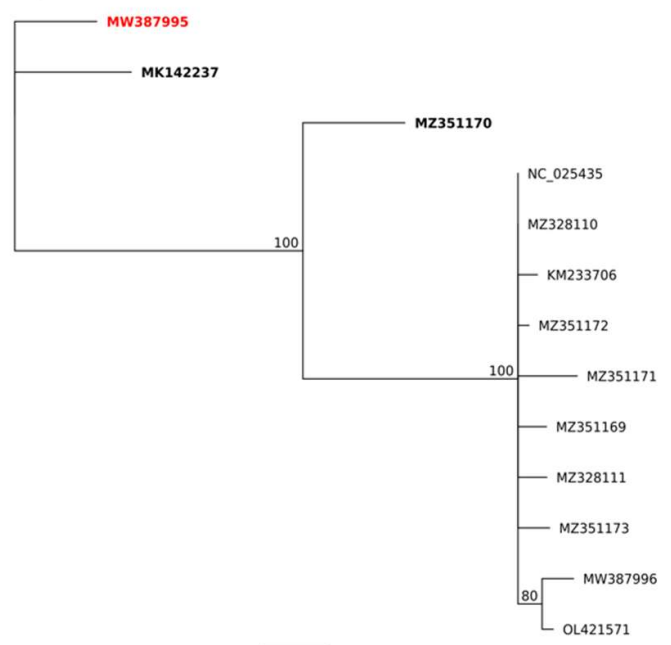

$\overline{0.01}$

Figure 6. Phylogenetic comparison of non-recombinant (A) and putative recombinant (B) parts of the P5 nucleotide sequences for the $5276 \mathrm{nt}$ breakpoint. The gene was divided according to the recombination points obtained by RDP5 program (the breaking point on $5276 \mathrm{nt}$ of alignment). Potential recombinants are in bold, the Rujana SPV1 isolate (the Czech recombinant) is in red, nucleotide positions are according to the NC_025435 reference. 


\section{Discussion}

There is limited knowledge about SPV1 occurrence worldwide. It was noted that estimation of biological significance is the key challenge that follows discovery of a new virus species [21]. In the current study, we focused on characterization of SPV1 occurrence, tested non-strawberry plants from close vicinity to sampling sites, then determined and experimentally verified its putative vectors.

SPV1 was first identified in strawberry samples from Canada by HTS. Due to its high incidence in strawberry plants on both American continents $[4,12-14]$ and from the present study in the Czech Republic (Central Europe) (35\% positive among 296 examined F. ananassa plants; $75 \%$ positive among 16 examined $F$. vesca $\mathrm{cv}$. Rujana plants), it can be assumed that SPV1 is present in production plantings in other countries in Europe and worldwide.

As previously described, strawberry viruses commonly occur in mixed infections [2,11,12,22]. Our survey confirmed this, as SPV1 was usually found in coinfections with other examined viruses (77\%, i.e., 89 plants out of 115$)$. Nevertheless, we were not able to establish an association between the type of symptoms and the presence of the five tested viruses. Prominent premature leaf reddening and death of strawberry plants at sites in South Moravian, Olomouc and Zlín regions were not usually associated with the presence of viruses, but fungi were identified at sites in Zlín Region. Previously, Phytphthora fragariae var. fragariae, Verticillium sp. and Rhizoctonia fragariae were described as associated with strawberry collapsing and severe damage [1]. As we detected Verticilium sp. and Rhizoctonia sp. in examined strawberries in Zlín Region, the symptoms of leaf reddening and plant death can be fungi-associated. On the other hand, the weakening of strawberry plant growth and premature leaf reddening and leaf decline on the farm in the Pilsen Region was related to the presence of viruses. Among 39 of these plants, only 2 were negative for all of the tested viruses, while 31 of them were positive for SPV1. However, the cause of premature dieback, especially in older plants, needs to be investigated comprehensively. For example, 2- to 3-year-old virus-positive plants of cv. Elkat often showed typical symptoms of viral disease, such as mosaic and irregular vein clearing. Similar symptoms have already been described in this cultivar during a StrV- 1 prevalence survey of StrV1-infected plants [7]. Interestingly, nine young cv. Elkat plants infected with various combinations of the tested viruses did not display any disease symptoms. Other cultivars showed rather nonspecific symptoms, such as leaf stunting, chlorosis, and curling.

The practices followed in a private garden in Třísov (SB-10-G) provide a typical example of the repeated cultivation of strawberries by hobby gardeners. Although the strawberries planted at this site were grown from seeds and were thus presumably virusfree, within one year, their further cultivation was terminated specifically because of virus infection. This was probably due to the simultaneous cultivation of $F$. vesca semperflorens, which seems to be a more attractive plant to aphids than F. ananassa. The other important factor is the presence of virus vectors, including other invertebrates (leafhoppers).

Detection of SPV1 amplicons by RT-PCR revealed possible SPV1 vectors and contributed to the understanding of the SVP1 cycle in nature. During the survey, we detected SPV1 sequences in all aphids colonizing SPV1-positive strawberries (oligophagous aphids: A. forbesi, A. ruborum, A. sanguisorbae, and C. fragaefolii; polyphagous aphids: A. gossypii, A. solani, and M. ascalonicus). We also found SPV1 sequences in honeydew produced by aphid colonies and in the bodies of ants. Honeydew serves as a food for ants, which probably explains why we detected SPV1 in ant bodies. However, ants can protect aphids against natural enemies and transport them to the most susceptible sites on individual plants, which may indirectly contribute to the spread of the virus from plant to plant. Leafhoppers are more commonly associated with phytoplasma diseases, and their role in SPV1 transmission remains unknown. The RT-PCR detection of SPV1 in the larva of the dirt-colored bug of the Rhyparochromidae family and in F. galba enchytraeids may be associated with feeding on diseased plants, but the role of these species in SPV1 transmission deserves further attention in future. Until recently, poleroviruses were thought to be 
transmitted solely by aphids. However, pepper whitefly-borne vein yellows virus was recently proven to be transmitted by the whitefly Bemisia tabaci [23]. Absence of SPV1 in plants other than Fragaria growing near strawberry fields might indicate a limited SPV1 host range, but it requires more attention in future as in the current study, numbers of tested plants for distinct species were quite limited. We may speculate that due to their perennial life cycle, Fragaria sp. may serve as the main SPV1 reservoir, if not the only one.

After the successful establishment of A. gossypii and C. fragaefolii. aphid colonies, we verified the hypothesis that these species can serve as natural vectors for SPV1. Although A. gossypii showed the highest SPV1 levels, transmission by single aphids with limited IAP (up to $48 \mathrm{~h}$ ) under the tested experimental conditions was not successful. Then, we performed these tests with $C$. fragaefolii, a known strawberry virus vector [10], and increased both the number of aphids per transmission and the IAP. When eight or more individuals (C. fragaefolii) were used with an unrestricted IAP, all recipient $F$. vesca 'Alpine' plants were infected. Successful SPV1 transmission was achieved by using 10-aphid batches with IAPs varying from 1 to 17 days. SPV1 was transmitted when both $F$. vesca semperflorens infected with multiple virus infection (Rujana 7/2017) as well as F. vesca 'Alpine' infected solely with SPV1 were used as source of inoculum. As an IAP of at least one day was needed, SPV1 was shown to be transmitted in a persistent manner, similar to other poleroviruses [24].

None of the eight SPV1-infected 'Alpine' plants showed any symptoms. Therefore, we assume that asymptomatic SPV1 may exist in 'Alpine' indicator plants. The symptoms of leaf curl and irregular vein clearing observed in SPV1- and SCV-positive 'Alpine' plants were likely due to mixed infections. Similar symptoms have been previously described as characteristic of mixed infections involving SVBV and latent A crinkle virus [10]. Therefore, molecular methods are indispensable for SPV1 detection.

During the survey, we analyzed the variability of the nucleotide sequences of the Czech SPV1 isolates. Interestingly, the F. ananassa isolates from distant localities showed nearly identical RdRP gene sequences, suggesting the potential spread of SPV1 via propagation material. Substantially different nucleotide sequences were identified in isolates from $F$. vesca semperflorens $\mathrm{cv}$. Rujana and the associated arthropods at one locality in South Bohemian region (Trísov, SB-10-G). Nevertheless, most of the identified nucleotide differences were synonymous (usually located at the 3rd position of the codon) and did not change the encoded amino acid. Detailed nucleotide comparisons revealed that the sources of SPV1 variation included not only single-nucleotide mutations but also the recombination of larger genomic fragments, similar to what has been reported previously for solemoviruses $[25,26]$. The majority of the observed nucleotide variability in the Rujana SPV1 isolate was identified in the P1 and P5 genes. As the P5 protein is related to the insect-mediated transmissibility of luteovirids [27-29], the preservation of its aa sequence suggests the existence of selection pressure on transmission by the involved insect species. Further nonsynonymous mutations or recombination in this region may, however, influence the transmissibility of the virus and/or its vector range in the future $[29,30]$. In the present study, one of the identified recombined fragments showed high similarity between the Rujana isolate and two American SPV1 isolates (H2429, H2400), and the second showed similarity to two other American isolates (15CA, H2470). The presence of these two fragments in one genome from the Rujana isolate, together with the other dissimilarities between the Rujana isolate and other sequences, may indirectly indicate that an isolate closely related to the Rujana isolate was a possible source from which these fragments recombined. The fact that the isolates potentially participating in recombination (or their descendants) are from geographically distant locations (America and Europe) emphasizes the need for further analyses of the host range of SPV1 and its vectors to not only understand its molecular biology but to also effectively reduce potential damage caused by the virus or new variants thereof. 


\section{Conclusions}

Ultimately, SPV1 was the most common virus in our survey, although it was not detected in all areas. Two-thirds of all identified cases involved coinfection with other strawberry viruses. Neither SPV1 nor any of other tested viruses alone was significantly associated with symptomatic phenotype. Interestingly, experimentally SPV1-infected $F$. vesca 'Alpine' strawberry indicator plants did not show any disease symptoms. Recombination events were documented within SPV1 genomes for the first time; however, their impact on biological traits is to be determined.

C. fragaefolii aphids were experimentally verified as an SPV1 vector with a persistent manner of transmission, requiring a minimal inoculation access period of 1 day. Successful SPV1 transmission was achieved when using at least eight aphids. Other aphid species (A. forbesi, A. gossypii, A. ruborum, A. sanguisorbae, A. solani and M. ascalonicus) were also SPV1-positive and are highly likely to contribute to virus transmission. Before consideration on inclusion of SPV1 into phytosanitary diagnostic protocols, given its high incidence rates it is necessary to verify impact of SPV1 infection on different strawberry varieties.

Supplementary Materials: The following are available online at https://www.mdpi.com/article/10 .3390 /v13122487/s1, Figure S1: Localities of sampling in the Czech Republic, Figure S2: Fragaria vesca 'Alpine' (No. 814) infected with strawberry polerovirus 1 (SPV1), strawberry mottle virus (SMoV) and strawberry crinkle virus (SCV) with mosaic, severe leaf malformation and dwarf symptoms, Figure S3: F. vesca 'Alpine' plant infected with SMoV showing severe mosaic on the 35th day post inoculation (dpi) with Aphis gossypii, Figure S4: Irregular vein clearing (arrow) and leaf curl of F. vesca 'Alpine' plant infected with SPV1 and SCV at 32 dpi with Chaetosiphon fragaefolii (source of inoculum: F. vesca cv. Rujana 7/2017), Figure S5: Phylogeny of aa sequences for particular genes of SPV1, Figure S6: Phylogeny of nt and aa partial sequences of P1-P2 gene (1600 nt fragment) of SPV1, Figure S7: Analysis of potential recombination events in P1 and P5 genes between available SPV1 isolates: (A) overview with nucleotide changes depicted; (B) RDP5 software recombination graphs and $p$-values obtained; (C) phylogenetic trees of recombined and non-recombined regions of particular genes, Table S1: Overview of the tested plants: symptoms, virus detection and Sanger sequencing of SPV1 isolates originating from strawberry plants from different localities of the Czech Republic, Table S2: Description of all primers used in the study, Table S3: Results of RT-PCR determination of SPV1 in Aphis gossypii batches and recipient Fragaria vesca 'Alpine' plants after transmission trials, Table S4: Synonymous vs. nonsynonymous nucleotide mutations in different parts of the P1 (A) and P5 (B) genes.

Author Contributions: Conceptualization, J.F., I.K. and O.L.; methodology, J.F., I.K. and O.L.; software, I.K. and O.L.; validation, J.F., I.K., O.L. and R.Č.; formal analysis, J.F., I.K., O.L. and R.Č.; investigation, J.F., I.K., O.L., J.P., R.Č. and L.V.; resources, J.F, J.P., I.K., L.V. and R.Č.; data curation, J.F., I.K., O.L. and R.Č..; writing—original draft preparation, J.F., I.K., O.L. and R.Č.; writing—review and editing, J.F., I.K. and O.L.; visualization, J.F., I.K. and O.L.; supervision, J.F., I.K. and O.L.; project administration, J.F. and R.Č.; funding acquisition, J.F., I.K. and R.Č. All authors have read and agreed to the published version of the manuscript.

Funding: This research was funded by the Ministry of Agriculture of the Czech Republic, the National Agency for Agricultural Research, projects QK1920245 and QJ1610365, and by institutional support from RVO60077344. Computational resources were supplied by the "e-Infrastruktura CZ" project (e-INFRA CZ ID:90140) supported by the Ministry of Education, Youth and Sports of the Czech Republic.

Institutional Review Board Statement: Not applicable.

Informed Consent Statement: Not applicable.

Data Availability Statement: The genomic sequences obtained in this study were submitted to the GenBank database under accession numbers MW387973-MW387997, OK181865, OK181896, OK181901, OK181906, OK181931, OK205264, OK275083, and OL421564-OL421571. 
Acknowledgments: We are deeply indebted to Jan Havelka (Institute of Entomology, Biology Centre CAS) for the morphological identification of invertebrates and Olga Baudysová, Jana Veselá, Alena Matyášová, and Jitka Mašková for their technical assistance.

Conflicts of Interest: The authors declare no conflict of interest.

\section{Appendix A. Potential Non-Strawberry SPV1 Hosts}

None of the following non-strawberry 42 plants (19 sp.) were identified as natural SPV1 hosts: Aegopodium podagraria L. $(n=1)$, Aster sp. $(n=1)$, Arabidopsis thaliana (L). Heynh. $(n=1)$, wild seedling of Betula pendula Roth $(n=1)$, Carex sp. $(n=1)$, Chenopodium sp. $(n=1)$, Epilobium parviflorum Schreb. $(n=1)$, Hypochaeris radicata L. $(n=1)$, Malus sp. $(n=10)$, Poa annua L. $(n=1)$, Potentilla sp. $(n=1)$, Prunus sp. (cherry: $n=2$, plum: $n=1)$, Rorippa palustris (L.) Besser $(n=1)$, Rumex obtusifolius L. $(n=1)$, wild seedling of Salix caprea L. $(n=1)$, Scorzoneroides autumnalis (L.) Moench. $(n=1)$, Sonchus arvensis L. $(n=4)$, Stellaria media (L.) Vill. $(n=5)$ and Taraxacum officinale Web. $(n=6)$. Polyphagous A. solani aphids were found on both strawberry plants and weedy plants of T. officinale; $A$. gossypii was observed on strawberries and E. parviflorum, H. radicata, S. autumnalis, S. arvensis, T. officinale and wild seedlings of B. pendula and S. caprea.

\section{Appendix B. Identification of Invertebrates/Vectors}

Sanger sequencing of the COI region from invertebrate samples confirmed the morphological identification of strawberry-associated aphids (Table A1) as well as Brachycaudus helichrysi (Kaltenbach, 1843) and Acyrthosiphon malvae (Mosley, 1841) found on Aster sp. and A. thaliana; Hyalopterus pruni (Geoffroy, 1762) and Aphis podagrariae (Schrank, 1801) found on a plum tree and $A$. podagraria growing among strawberries. Furthermore, two collected leafhoppers were identified as unclassified Anaceratagallia sp.; collected enchytraeids were identified as Fridericia galba (Hoffmeister, 1843) $(n=3)$; and collected ants were identified as Tetramorium impurum (Foerster, 1850) $(n=2)$. The COI sequences were deposited in GenBank (Table A1). The PCR amplification of the COI region from the larva of a dirt-colored seed bug failed; therefore, this species was identified only on the basis of morphology as a member of the family Rhyparochromidae.

Table A1. Results of RNA extraction and the identification of SPV1-positive invertebrates by the amplification of cytochrome oxidase 1 (COI).

\begin{tabular}{llll}
\hline $\begin{array}{l}\text { Invertebrate } \\
\text { Identification }\end{array}$ & RNA, ng/ $\boldsymbol{\mu L}$ & COI, GenBank Acc. No. & Host Plant Isolate \\
\hline $\begin{array}{l}\text { Anaceratagallia sp. } \\
\begin{array}{l}\text { Hemiptera: Cicadellidae } \\
\text { Anaceratagallia sp }\end{array}\end{array}$ & 182.7 & OK205264 & F. vesca cv. Rujana_1/2017_CBI \\
$\begin{array}{l}\text { Hemiptera: Cicadellidae } \\
\text { Aphis gossypii }\end{array}$ & 175.6 & OK275083 & F. vesca cv. Rujana_1/2017_CBII \\
$\begin{array}{l}\text { Hemiptera: Aphididae } \\
\text { Aphis ruborum }\end{array}$ & 77.3 & OK181865 & F. ananassa cv. Čačanská raná_ČRM3 \\
$\begin{array}{l}\text { Hemiptera: Aphididae } \\
\text { Aphis sanguisorbae }\end{array}$ & 134.2 & OK181931 & F. vesca cv. Rujana_1/2017 \\
$\begin{array}{l}\text { Hemiptera: Aphididae } \\
\text { Aulacorthum solani }\end{array}$ & 224.5 & MN420509 & F. ananassa cv. Čačanská raná_ČRM3 \\
$\begin{array}{l}\text { Hemiptera: Aphididae } \\
\text { Chaetosiphon fragaefolii }\end{array}$ & 53.6 & MN420511 & F. vesca cv. Rujana_1/2017 \\
$\begin{array}{l}\text { Hemiptera: Aphididae } \\
\text { Myzus ascalonicus }\end{array}$ & 134.1 & MN420510 & F. vesca cv. Rujana_7/2017 \\
Hemiptera: Aphididae & 228.9 & OK181896 & F. vesca cv. Rujana_1/2017 \\
\hline
\end{tabular}


Table A1. Cont.

\begin{tabular}{|c|c|c|c|}
\hline $\begin{array}{l}\text { Invertebrate } \\
\text { Identification }\end{array}$ & RNA, ng/ $\mu \mathrm{L}$ & COI, GenBank Acc. No. & Host Plant Isolate \\
\hline $\begin{array}{l}\text { Rhyparochromidae sp. } \\
\text { Hemiptera }\end{array}$ & 305.3 & n. a. & F. vesca cv. Rujana_1/2017 \\
\hline $\begin{array}{l}\text { Tetramorium impurum } \\
\text { Hymenoptera: Formicidae } \\
\text { Fridericia galba }\end{array}$ & 6.8 & OK181901 & F. ananassa_34/2016 \\
\hline $\begin{array}{l}\text { Enchytradeida: } \\
\text { Enchytraeidae }\end{array}$ & 12.4 & OK181906 & F. ananassa cv. Laetitia_169/2020 \\
\hline
\end{tabular}

n. a.-not available.

\section{Appendix C. Detection of SPV1 in Invertebrates and Honeydew}

Through RT-PCR with SPV-1F/SPV-1R primers, SPV1 was detected in all aphid species feeding on SPV1-positive strawberries (e.g., A. forbesi, A. gossypii, A. ruborum, A. sanguisorbae, A. solani, M. ascalonicus and C. fragaefolii (Table A1)). PCR products of low intensity but of an expected size were obtained using cDNA preparations from leafhoppers, enchytraeids, ants, and dirt-colored seed bug larva samples. Sanger sequencing confirmed the presence of SPV1 in all RT-PCR positive samples. The SPV1 sequences from all invertebrates were identical to those of the corresponding host plant virus isolates.

The amplification of viral cDNA from honeydew samples revealed bands of strong intensity. Sanger sequencing with the primer pairs Polero $47 \mathrm{fw} / 2 \mathrm{rv}$ and Polero $2 \mathrm{fw} / 40 \mathrm{rv}$ revealed shared identity with SPV1 sequences from the host plants F. vesca cv. Rujana (Acc. No. MW387973) and F. ananassa ČRM3.

No SPV1 was detected in aphids feeding on weedy plants or from Lygus rugulipennis Poppius, $1911(n=3)$, Rhopalus sp. $(n=3)$, Philaenus sp. $n=1)$, the pollen beetle Meligethes aeneus Fabricius $1775(n=5)$, the 22-spot ladybird Psyllobora vigintiduopunctata Linnaeus, 1758 (larva: $n=1)$, Phyllopertha horticola Linnaeus $1758(n=3)$, the grasshopper Chorthippus biguttulus Linnaeus, $1758(n=1)$, Chrysoperla sp. (larvae: $n=2$, adult: $n=1)$, unidentified true bug larvae $(n=4)$, unidentified leafhopper sp. $(n=7)$, whiteflies $(n=5)$, an Ephemeroptera mayfly $(n=1)$, Plutella sp. $(n=2)$ or a longhorn beetle (Cerambycidae) $(n=1)$.

\section{Appendix D. SPV1 Load in Individual Aphids}

After the RT-PCR detection of SPV1 in A. sanguisorbae, A. gossypii and C. fragaefolii, the estimation of viral titers in individual aphids was performed (Figure A1).

One-way ANOVA revealed a statistically significant difference in the levels of SPV1specific RNA between at least two groups $(p=0.0006)$. Post hoc Tukey's test indicated that the mean values were significantly different between A. gossypii and C. fragaefolii ( $p=0.0004$, $95 \%$ confidence interval $=[6.1,465.9])$, while other comparisons showed no significant differences (A. gossypii vs. A. sanguisorbae $-p=0.07$ and $C$. fragaefolii vs. A. sanguisorbae$p=0.09$ ). Using the analyzed data, $A$. gossypii aphids were selected as an optimal vector for further transmission experiments. 


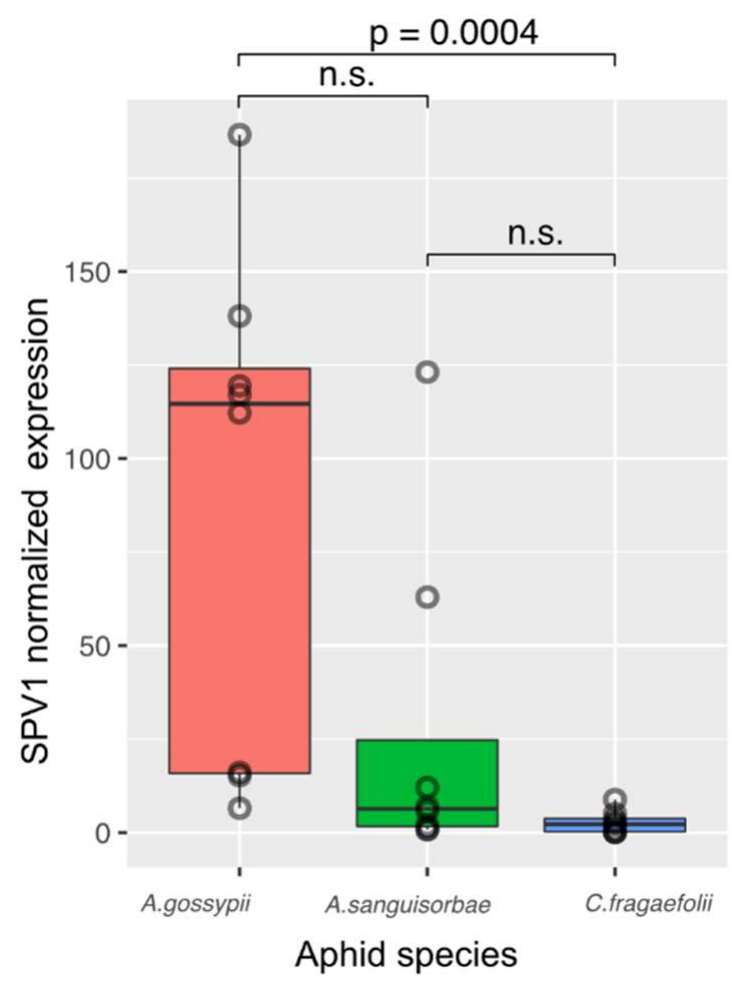

Figure A1. Boxplot of normalized expression values of SPV1 in three aphid species. Individual data points were overplotted as circles to show the distribution of measurements. Chaetosiphon fragaefolii showed the lowest SPV1 expression values and was therefore selected as a control group for comparison. n.s.-statistically nonsignificant difference.

\section{References}

1. Maas, J.L. Compendium of Strawberry Diseases, 2nd ed.; APS Press: St. Paul, MN, USA, 1998.

2. Martin, R.R.; Tzanetakis, I.E. Characterization and Recent Advances in Detection of Strawberry Viruses. Plant Dis. 2006, 90, 384-396. [CrossRef]

3. Ho, T.; Tzanetakis, I.E. Development of a virus detection and discovery pipeline using next generation sequencing. Virology 2014, 471-473, 54-60. [CrossRef]

4. Xiang, Y.; Bernardy, M.; Bhagwat, B.; Wiersma, P.A.; Deyoung, R.; Bouthillier, M. The complete genome sequence of a new polerovirus in strawberry plants from eastern Canada showing strawberry decline symptoms. Arch. Virol. 2014, 160, 553-556. [CrossRef]

5. Ding, X.; Li, Y.; Hernández-Sebastià, C.; Abbasi, P.A.; Fisher, P.; Celetti, M.J.; Wang, A. First Report of Strawberry crinivirus 4 on Strawberry in Canada. Plant Dis. 2016, 100, 1254. [CrossRef]

6. Ding, X.; Chen, D.; Du, Z.; Zhang, J.; Wu, Z. The complete genome sequence of a novel cytorhabdovirus identified in strawberry (Fragaria ananassa Duch). Arch. Virol. 2019, 164, 3127-3131. [CrossRef] [PubMed]

7. Fránová, J.; Přibylová, J.; Koloniuk, I. Molecular and Biological Characterization of a New Strawberry Cytorhabdovirus. Viruses 2019, 11, 982. [CrossRef]

8. Lenz, O.; Přibylová, J.; Fránová, J.; Koloniuk, I. Fragaria vesca-associated virus 1: A new virus related to negeviruses. Arch. Virol. 2020, 165, 1249-1252. [CrossRef]

9. He, C.; Gao, D.; Fan, L.; Xu, T.; Xing, F.; Li, S.; Wang, H. The Occurrence of Strawberry Virus 1 Infecting Strawberry in Shandong Province, China. Plant Dis. 2021, in press. [CrossRef]

10. Converse, R.H. Virus Disease of Small Fruits, 1st ed.; United States Department of Agriculture: Washington, DC, USA, 1987; pp. 1-288.

11. Martin, R.R.; Tzanetakis, I.E. High Risk Strawberry Viruses by Region in the United States and Canada: Implications for Certification, Nurseries, and Fruit Production. Plant Dis. 2013, 97, 1358-1362. [CrossRef]

12. Diaz-Lara, A.; Stevens, K.A.; Klaassen, V.; Hwang, M.S.; Al Rwahnih, A. Sequencing a strawberry germplasm collection reveals new viral genetic diversity and the basis for new RT-qPCR assays. Viruses 2021, 13, 1442. [CrossRef] [PubMed]

13. Thekke-Veetil, T.; Tzanetakis, I.E. First report of strawberry polerovirus-1 in strawberry in the United States. Plant Dis. 2016, 100, 867. [CrossRef] 
14. Luciani, C.E.; Celli, M.G.; Merino, M.C.; Perotto, M.C.; Pozzi, E.; Conci, V.C. First Report of Strawberry polerovirus 1 in Argentina. Plant Dis. 2016, 100, 1510. [CrossRef]

15. Sõmera, M.; Fargette, D.; Hébrard, E.; Sarmiento, C. ICTV Report consortium. ICTV virus taxonomy profile: Solemoviridae. J. Gen. Virol 2021, in press.

16. Folmer, O.; Black, M.; Hoeh, W.; Lutz, R.; Vrijenhoek, R. DNA primers for amplification of mitochondrial cytochrome coxidase subunit I from diverse metazoan invertebrates. Mol. Mar. Biol. Biotech. 1994, 3, 294-299.

17. Thompson, J.R.; Wetzel, S.; Klerks, M.M.; Vašková, D.; Schoen, C.D.; Špak, J.; Jelkmann, W. Multiplex RT-PCR detection of four aphid-borne strawberry viruses in Fragaria spp. in combination with a plant mRNA specific internal control. J. Virol. Methods 2003, 111, 85-93. [CrossRef]

18. R Core Team. R: A Language and Environment for Statistical Computing; R Foundation for Statistical Computing: Vienna, Austria, 2021. Available online: https:/ / www.R-project.org/ (accessed on 7 June 2021).

19. Conway, J.R.; Lex, A.; Gehlenborg, N. UpSetR: An R package for the visualization of intersecting sets and their properties. Bioinformatics 2017, 33, 2938-2940. [CrossRef] [PubMed]

20. Martin, D.P.; Varsani, A.; Roumagnac, P.; Botha, G.; Maslamoney, S.; Schwab, T.; Kelz, Z.; Kumar, V.; Murrell, B. RDP5: A computer program for analyzing recombination in, and removing signals of recombination from, nucleotide sequence datasets. Virus Evol. 2021, 7, veaa087. [CrossRef]

21. Massart, S.; Candresse, T.; Gil, J.F.; Lacomme, C.; Predajna, L.; Ravnikar, M.; Reynard, J.-S.; Rumbou, A.; Saldarelli, P.; Škorić, D.; et al. A Framework for the Evaluation of Biosecurity, Commercial, Regulatory, and Scientific Impacts of Plant Viruses and Viroids Identified by NGS Technologies. Front. Microbiol. 2017, 8, 45. [CrossRef] [PubMed]

22. Ghosh, S.; Kanakala, S.; Lebedev, G.; Kontsedalov, S.; Silverman, D.; Alon, T.; Mor, N.; Sela, N.; Luria, N.; Dombrovsky, A.; et al. Transmission of a New Polerovirus Infecting Pepper by the Whitefly Bemisia tabaci. J. Virol. 2019, 93, 00488-19. [CrossRef]

23. Fereres, A.; Raccah, B. 2015 Plant virus transmission by insects. In eLS; John Wiley \& Sons, Ltd.: Chichester, UK, $2015 ;$ pp. 1-12.

24. Silva, T.; Corrêa, R.; Castilho, Y.; Silvie, P.; Bélot, J.-L.; Vaslin, M. Widespread distribution and a new recombinant species of Brazilian virus associated with cotton blue disease. Virol. J. 2008, 5, 123. [CrossRef]

25. Ellis, M.H.; Silva, T.F.; Stiller, W.N.; Wilson, L.J.; Vaslin, M.; Sharman, M.; Llewellyn, D. Identification of a new Polerovirus (family Luteoviridae) associated with cotton bunchy top disease in Australia. Australas. Plant Pathol. 2013, 42, 261-269. [CrossRef]

26. Brault, V.; Heuvel, J.V.D.; Verbeek, M.; Ziegler-Graff, V.; Reutenauer, A.; Herrbach, E.; Garaud, J.; Guilley, H.; Richards, K.; Jonard, G. Aphid transmission of beet western yellows luteovirus requires the minor capsid read-through protein P74. EMBO J. 1995, 14, 650-659. [CrossRef]

27. Brault, V.; Périgon, S.; Reinbold, C.; Erdinger, M.; Scheidecker, D.; Herrbach, E.; Richards, K.; Ziegler-Graff, V. The Polerovirus Minor Capsid Protein Determines Vector Specificity and Intestinal Tropism in the Aphid. J. Virol. 2005, 79, 9685-9693. [CrossRef]

28. Mutterer, J.D.; Stussi-Garaud, C.; Michler, P.; Richards, K.E.; Jonard, G.; Ziegler-Graff, V. Role of the beet western yellows virus readthrough protein in virus movement in Nicotiana clevelandii. J. Gen. Virol. 1999, 80, 2771-2778. [CrossRef] [PubMed]

29. Costa, T.M.; Blawid, R.; Aranda, M.A.; Freitas, D.M.S.; Andrade, G.P.; Inoue-Nagata, A.K.; Nagata, T. Cucurbit aphid-borne yellows virus from melon plants in Brazil is an interspecific recombinant. Arch. Virol. 2018, 164, 249-254. [CrossRef] [PubMed]

30. Paredes, C.; Rosales, L.S.; Gallegos, V.; Castellanos, M.; Garfias, A.E.J.Y.; González, P. Incidence of mixed viral infections in a strawberry producing area in Guanajuato, Mexico. Rev. Mex. Fitopatol. (En Linea) 2014, 32, 12-25. 